\title{
Simulated Drought Induces High Caffeic Acid Contents in Storage Root Periderm of Greenhouse Grown Sweetpotatoes
}

\author{
Howard F. Harrison ${ }^{1}$ and Joseph K. Peterson \\ U.S. Vegetable Laboratory, U.S. Department of Agriculture, Agricultural \\ Research Service, 2700 Savannah Highway, Charleston, SC 29407
}

\author{
Maurice E. Snook \\ Russell Research Center, U.S. Department of Agriculture, Agricultural Research \\ Service, Room 348, 950 College Station Road, Athens, GA 30601
}

Additional index words. Ipomoea batatas, phenolics, stress

Caffeic acid is one of several phenolic compounds that occur in sweetpotato [Ipomoea batatas L. (Lam.)] storage roots and other tissues (Islam et al., 2002; Son et al., 1991). Such compounds are considered to be an important part of the general defense mechanism of plants against infection and predation (Faulds and Williamson, 1999). Caffeic acid inhibits the growth of plants (Baghestani et al., 1999; Miller et al., 1991; Singh et al., 1989), fungi (Bostock et al., 1999; Kasenberg and Traquair, 1987; Kuc et al, 1956; Ravn et al, 1989), bacteria (Bowles and Miller, 1994; Reinders et al., 2001) and insects (Summers and Felton, 1994).

We reported that some sweetpotato clones contained high levels of caffeic acid in periderm tissue (Harrison et al., 2003) that comprises the outer layer of sweetpotato storage and fleshy feeder roots. Caffeic acid contents ranged from 7.97 to $0.04 \mathrm{mg} \cdot \mathrm{g}^{-1}$ periderm dry weight. Although relative caffeic acid contents of a genetically diverse group of sweetpotato clones were fairly consistent from one environment to another, there were large differences between environments in the average content across clones. This indicates that environmental conditions affect periderm caffeic acid contents. The cause of the environmental effect is not known, but due to differences in rainfall and irrigation, it appeared likely that moisture stress varied between environments. The objective of this experiment was to determine the effect of simulated drought stress on sweetpotato storage root caffeic acid contents in a greenhouse experiment.

Seven sweetpotato clones - two commercial cultivars (Beauregard and Jewel), three advanced experimental lines (W311, W325, and 97-82), and two plant introductions (PI 539141 and PI 595855) — were selected based on their variation in periderm caffeic acid content in the previous study (Harrison et al.,

\footnotetext{
Received for publication 28 July 2005 . Accepted for publication 21 Oct. 2005. Mention of a trademarkname or proprietary product does not constitute a warranty or guarantee by the USDA, nor does it imply exclusion of other products that may also be suitable.

${ }^{1}$ To whom request for reprints should be addressed; e-mail hharrison@saa.ars.usda.gov.
}

2003). Sweetpotato vine cuttings were planted in $12-\mathrm{L}$ polyethylene pots filled with a $50 \%$ (by volume) mixture of washed builder's sand and Metro-Mix 360 (Grace Sierra, Milpitas, Calif.). Powdered limestone ( $25 \mathrm{~g}$ ), controlledrelease fertilizer (25 g) (Osmocote 14N-6.1 P - 11.6 K, Scotts Sierra Horticultural Products, Marysville, Ohio), and imidacloprid insecticide $(0.15 \mathrm{~g})$ (1-[(6-Chloro-3-pyridinyl)methyl]$\mathrm{N}$-nitro-2-imidazolidinimine) (Marathon II; Olympic Horticultural Products, Mainland, Pa.) were added to each pot. The planting dates were 29 Sept. 2000 for Expt. 1 and 11 Nov. 2001 for Expt. 2. Sweetpotatoes were grown in a greenhouse, vines were supported by wire cages to prevent intertwining, and insecticides were used as necessary to maintain plant health. Supplemental lighting was not provided, relative humidity varied with the ambient, and greenhouse temperatures ranged between 20 and $35^{\circ} \mathrm{C}$. Plants were subjected to simulated drought stress three times during the course of the experiment by withholding water until tensiometer (model 2725ARL18-R; Soil Moisture Equipment Corp., Goleta, Calif.) readings reached $50 \mathrm{cB}$. Drought stress treatments were initiated at 9,16 , and 20 weeks after planting. During the drought stress period, each pot was checked daily with a tensiometer after the appearance of the plant indicated the onset of stress. Watering was resumed for pots individually when the tensiometer reading reached $50 \mathrm{cB}$ after the first two stress treatments. The experiment was terminated, and storage roots were harvested after the third stress treatment. For control plants and drought stressed plants between treatments, the potting medium was kept at a moisture level equivalent to field capacity by daily surface and subsurface watering (tensiometer readings in watered pots ranged between 0 and $5 \mathrm{cB}$ ). At the end of the experiment, storage roots were removed from pots, washed, and separated into periderm, cortex and stele tissues. Periderm was removed from cortex by scraping gently with the sharp edge of a scalpel. This procedure works well with freshly dug roots but is less effective with cured roots, because the periderm becomes more firmly attached with curing. Periderm thickness was determined by measuring the dry weight of periderm removed from a known storage root surface area. The tissues were lyophilized and stored under nitrogen at $-20^{\circ} \mathrm{C}$. Caffeic acid was extracted, and contents were determined by reverse phase high performance liquid chromatography as previously described (Harrison et al, 2003). The identity of caffeic acid was confirmed by spectroscopic analysis and co-chromatography with an authentic standard.

The experiment was arranged in a randomized complete block design with four replications. Experimental units consisted of one pot. Caffeic acid content and periderm thickness data were subjected to analysis of variance. Single degree of freedom $\mathrm{F}$ tests at $P \leq 0.05$ were used to determine differences between the means of drought stressed and control plants within experiments and clones. Since factorial analyses indicated that there were interactions between treatments and experiments, data from the two experiments are presented separately.

Sweetpotato plants exhibited severe wilting and leaf loss during the moisture stress treatments; however, they recovered and grew normally after watering was resumed. Periderm caffeic acid contents averaged across all clones were $>20$ times higher for drought stressed plant (1141 and $1982 \mu \mathrm{g} \cdot \mathrm{g}^{-1}$ dry weight in Expts. 1 and 2, respectively) than for nonstressed plants ( 45 and $84 \mu \mathrm{g} \cdot \mathrm{g}^{-1}$ dry weight in Expts. 1 and 2, respectively) (Table 1). Based on single degree of freedom $F$ tests, caffeic acid levels were higher for drought stressed plants than for controls for all comparisons except ' $\mathrm{W}-325$ ' in Expt. 1. This indicates that differences in moisture stress may have caused the variability in periderm caffeic acid contents between environments observed in previous field experiments (Harrison et al, 2003). Interactions between experiments and treatments indicated that the results of the experiments were different. Across clones, periderm caffeic acid content and periderm thickness of drought stressed or nonstressed plants were higher in Expt. 2 than in Expt. 1. We have no explanation for this difference; however, drought stress increased periderm caffeic acid contents to a similar degree in both experiments.

Caffeic acid contents in cortex and stele tissues (data not presented) were consistently very low in comparison to periderm tissue. This concurs with our previous observation (Harrison et al., 2003) that accumulation of high caffeic acid contents in sweetpotato storage roots is restricted to the periderm. Averaged across all clones, the periderm caffeic acid content in the control treatments were greater than ten fold lower than the average contents from previous field experiments. The virtual absence of moisture stress experienced by control plants in this experiment may be unlikely in the field, or other factors that were absent in the greenhouse may stimulate caffeic acid accumulation in the field.

Across all clones, periderms of storage roots from moisture stressed plants were thicker than those of control plants. For individual 
Table 1. Effect of simulated drought stress on storage root periderm caffeic acid content and thickness for seven sweetpotato clones grown in the greenhouse.

\begin{tabular}{|c|c|c|c|c|c|}
\hline \multirow{2}{*}{$\begin{array}{l}\text { Sweetpotato } \\
\text { clone }\end{array}$} & \multirow{2}{*}{$\begin{array}{l}\text { Drought } \\
\text { stress }\end{array}$} & \multicolumn{2}{|c|}{$\begin{array}{l}\text { Caffeic acid content } \\
\left(\mu \mathrm{g} \cdot \mathrm{g}^{-1} \text { dry wt }\right)\end{array}$} & \multicolumn{2}{|c|}{$\begin{array}{l}\text { Periderm thickness } \\
\qquad\left(\mathrm{mg} \cdot \mathrm{cm}^{-2}\right)\end{array}$} \\
\hline & & Expt. $1^{z}$ & Expt. 2 & Expt. 1 & Expt. 2 \\
\hline \multirow{2}{*}{ Beauregard } & - & 81 & 22 & 1.25 & 1.60 \\
\hline & + & $1158 \mathrm{a}^{\mathrm{y}}$ & $1010 \mathrm{a}$ & 1.60 & $2.12 \mathrm{a}$ \\
\hline \multirow[t]{2}{*}{ Jewel } & - & 19 & 5 & 0.43 & 1.12 \\
\hline & + & 903 a & $1003 \mathrm{a}$ & $0.86 \mathrm{a}$ & $1.49 \mathrm{a}$ \\
\hline \multirow[t]{2}{*}{ PI 539141} & - & 147 & 21 & 0.87 & 1.29 \\
\hline & + & $2532 \mathrm{a}$ & 774 a & 1.11 & $2.11 \mathrm{a}$ \\
\hline \multirow[t]{2}{*}{ PI 595855} & - & 0 & 32 & 1.16 & 1.63 \\
\hline & + & $2082 \mathrm{a}$ & $4025 \mathrm{a}$ & 1.24 & $2.08 \mathrm{a}$ \\
\hline \multirow[t]{2}{*}{ W-311 } & - & 43 & 250 & 0.96 & 1.74 \\
\hline & + & 648 a & $3480 \mathrm{a}$ & 1.43 & 2.00 \\
\hline \multirow[t]{2}{*}{$\mathrm{W}-325$} & - & 19 & 178 & 0.81 & 1.48 \\
\hline & + & 300 & $2122 \mathrm{a}$ & $1.70 \mathrm{a}$ & $1.71 \mathrm{a}$ \\
\hline \multirow[t]{2}{*}{$97-82$} & - & 4 & 81 & 0.20 & 1.81 \\
\hline & + & $362 \mathrm{a}$ & 1462 a & 0.87 & $2.69 \mathrm{a}$ \\
\hline \multirow[t]{2}{*}{ Mean } & - & 45 & 84 & 0.65 & 1.53 \\
\hline & + & 1141 & 1982 & 1.26 & 2.03 \\
\hline \multicolumn{6}{|c|}{ Analysis of variance $(\mathrm{F} \text { value })^{\mathrm{x}}$} \\
\hline \multicolumn{2}{|c|}{ Clone } & $5.02^{* *}$ & $21.16^{* *}$ & $7.22^{* *}$ & $11.94^{* *}$ \\
\hline \multicolumn{2}{|c|}{ Stress } & $50.68^{* *}$ & $295.58^{* *}$ & $23.44^{* * *}$ & $65.80^{* *}$ \\
\hline \multicolumn{2}{|c|}{ Clone $\times$ stress } & $4.35^{* *}$ & $18.99^{* *}$ & $1.20^{\mathrm{NS}}$ & $2.64^{*}$ \\
\hline
\end{tabular}

${ }^{2}$ Planting dates were 29 Sept. 2000 for Expt. 1 and 11 Nov. 2001 for Expt. 2.

'Mean periderm caffeic acid content or thickness of stressed plants followed by "a" are significantly greater than the mean of nonstressed plant above based on the single degree of freedom $\mathrm{F}$ test at $P \leq 0.05$.

$\mathrm{NS}, *, * *^{*} \mathrm{The} \mathrm{F}$ values are nonsignificant or significant at $P \leq 0.05$ or 0.001 , respectively.

clones, periderms of moisture stressed plants were thicker than control periderms for Jewel and $\mathrm{W}-325$ in Expt. 1 and for all clones except $\mathrm{W}-311$ in Expt. 2. These data also demonstrate that differences in thickness between clones may be greater than the difference within a clone induced by drought stress. Increases in both periderm thickness and caffeic acid concentration in periderm tissue contribute to the raised level of the important defense compound at the storage root surface of drought stressed plants.

\section{Literature Cited}

Baghestani, A.C., G.D. Lemieux, G.D. Leroux, R. Baziramkenga, and R.R. Simard. 1999. Determination of allelochemicals in spring cereal cultivars of different competitiveness. Weed Sci. 47:498-504.

Bostock, R.M., S.M.Wilcox, G. Wand, and J.E. Adaskaveg. 1999. Suppression of Monilinia fructicola cutinase production by peach fruit surface phenolic acids. Physiol. Mol. Plant Pathol. 54:37-50.

Bowles, B.L. and A.J. Miller. 1994. Caffeic acid activity against Clostridium botulinum spores. J. Food Sci. 59:905-908.

Faulds, C.B. and G. Williamson. 1999. The role of hydroxycinnamates in the plant cell wall. J. Sci.
Food Agr. 79:393-395.

Harrison, H.F., J.K. Peterson, M.E. Snook, J.R. Bohac, and D.M. Jackson. 2003. Quantity and potential biological activity of caffeic acid in sweet potato storage root periderm. J. Agr. Food Chem. 51:2943-2948.

Islam, M.S., M. Yoshimoto, S. Yahara, S. Okuno, K. Ishiguro, and O. Yamakawa. 2002. Identification and characterization of foliar polyphenolic composition in sweetpotato (Ipomoea batatas L.) genotypes. J. Agr. Food Chem. 50:3718-3722.

Kasenberg, T.R. and J.A. Traquair. 1987. Effects of phenolics on growth of Fusarium oxysporum f.sp. radicis-lycopersici in vitro. Can. J. Bot. 66:1174-1177.

Kuc, R.E., R.E Henze, A.J. Ullstrup, and F.W. Quackenbush. 1956. Chlorogenic and caffeic acids as fungistatic agents produced by potatoes in response to inoculation with $\mathrm{Hel}$ minthosporum carbonum. J. Amer. Chem. Soc. 78:3123-3125.

Miller, H.G., M. Ikawa, and L.C. Pierce. 1991. Caffeic acid identified as an inhibitory compound in asparagus root filtrate. HortScience 26:1525-1527.

Ravn, H., C. Andary, G. Kovacs, and P. Molgaard. 1989. Caffeic acid esters as in vitro inhibitors of plant pathogenic bacteria and fungi. Biochem. Sys. Ecol. 17:175-184.

Reinders, R.D., S. Biesterveld, and P.G.H. Bijker. 2001. Survival of Escherichia coli O157: H7 ATCC 43895 in a model apple juice medium with different concentrations of proline and caffeic acid. Appl. Environ. Microbiol. 67:2863-2866.

Singh, M., R.V.Tamma, and H.N. Nigg. 1989. HPLC identification of allelopathic compounds from Lantana camara. J. Chem. Ecol. 15:81-87.

Son, K-C., R.R. Severson, M.E. Snook, and S.J. Kays. 1991. Root carbohydrate, organic acid and phenolic chemistry in relation to sweetpotato weevil resistance. HortScience 26:1305-1308.

Summers, C.B. and G. W. Felton. 1994. Prooxidant effects of phenolic acids on the generalist herbivore Helicoverpa zea (Lepidoptera: Noctuidae): potential mode of action for phenolic compounds in plant anti-herbivore chemistry. Insect Biochem. Mol. Biol. 24:943-953. 